\title{
OPTIMALISASI PERAN DAN FUNGSI GURU BIMBINGAN DAN KONSELING DALAM IMPLEMENTASI KURIKULUM 13
}

\author{
Nanik Nurhayati
}

Guru Bk Smp Kab. Bondowoso, nanikn916@gmail.com

\section{SitiNurfarida Pw}

Guru Bk Smp Kab. Bondowoso, oshinpw@gmail.com

\begin{abstract}
Abstrak
Dalam rangka mengoptimalkan peran dan fungsi Guru Bimbingan dan Konseling di sekolah maka perlu kiranya mensosialisasikan pemahaman dan pengertian terhadap beberapa kebijakan yang memuat tentang peran dan fungsi Guru Bimbingan dan Konseling/Konselorkepada komponen sekolah serta menggugurkan adanya anggapan bahwa guru Bimbingan dan Konseling hanya mengatasi konseli bermasalah saja.Disamping itu Guru Bimbingan dan Konseling/konselor juga perlu memahami peran dan fungsinya. Guru Bimbingan dan Konseling/Konselor hendaknya melakukan penguatan dan penegasan peran dan identitas profesi guru Bimbingan dan Konseling/Konselor, Guru Bimbingan dan Konseling/konselor harus menunjukkan kinerjanya secara profesional, menjalankan peran dan fungsi secara optimal dalam membantu peserta didik dalam mengembangkanpotensi dirinya Guru Bimbingan dan Konseling harus mempunyai komitmen yang tinggi dalam upaya meningkatkan kualifikasi dan kemampuan profesionalnya untuk mencapai standar profesi sesuai yang ditetapkan
\end{abstract}

Kata Kunci : Peran dan Fungsi, Guru BK, Implementasi Kurikulum 13

\begin{abstract}
In order to optimize the role and function of Teacher Guidance and Counseling in schools, it is necessary to socialize the understanding and understanding of several policies that contain the role and function of the Guidance and Counseling / Counselor Teachers to the school components and abort the assumption that the Guidance and Counseling teachers only help to solve the problematic counselees and also some Guidance and Counseling Teachers / Counselors who have not understand abouth her/his the role and function. In order to optimize the role and function of Guidance and Counseling / Counselor Teachers; there are several things that must be done such as; 1 . to enrichment the role; 2 . have to show the professionalism well; 3. help the students to choose and to establish the interest and idea"mprefessionally; 4. having a high commitment in effort to improve their qualifications and abilities to achieve the specified professional standards.

Keywords: Roles and Functions, BK Teachers, Implementation of Curriculum 13
\end{abstract}




\section{PENDAHULUAN}

\section{Latar Belakang (gabungan ahli dan pengalaman di lapangan)}

Sesuai dengan arah dan spirit Kurikulum 2013, paradigma bimbingan dan konseling memandang bahwa setiap peserta didik/konseli memiliki potensi untuk berkembang secara optimal. Perkembangan optimal bukan sebatas tercapainya prestasi sesuai dengan kapasitas intelektual dan minat yang dimiliki, melainkan sebagai sebuah kondisi perkembangan yang memungkinkan konseli mampu mengambil pilihan dan keputusan secara sehat dan bertanggungjawab, memiliki daya adaptasi tinggi terhadap dinamika kehidupan yang dihadapinya serta berkembangnya potensi konseli agar menjadi manusia yang beriman dan bertakwa kepada Tuhan Yang Maha Esa, berakhlak mulia, sehat, berilmu, cakap kreatif, mandiri, dan menjadi warga negara yang demokratis serta bertanggungjawab.

Maka dari itu diperlukan Layanan bimbingan dan konseling dalam upaya membantu peserta didik/konseli mencapai tugas perkembangan diri yang optimal, mandiri, sukses, sejahtera dan bahagia dalam kehidupannya. Agar tujuan tersebut tercapai diperlukan kolaborasi dan sinergisitas kerja antara konselor atau guru bimbingan dan konseling, guru mata pelajaran, pimpinan sekolah/madrasah, staf administrasi, orang tua, dan pihak lainyang dapat membantu kelancaran proses dan pengembangan peserta didik/konseli secara utuh dan optimal dalam bidang pribadi, sosial, belajar, dan karir.

Kenyataan di lapangan pelaksanaan layanan Bimbingan dan Konseling belum maksimal. Hal ini disebabkan masih dijumpaiguru bimbingan dan konseling/konselor sekolah yang diberi tugas mengajar bidang studi seperti yang pernah penulis alami, bahkan mengurus hal-hal yang bertentangan dengan tugas pokok dan fungsi Bimbingan dan Konseling, seperti menjadi petugas piket, urusan kesiswaan/pembina OSIS, perpustakaan, koperasi, dsb. Tugas-tugas tersebut akan menjadikan bimbingan dan konseling tidak dilaksanakan secara profesional.
Kondisi tersebut berdampak pada pelaksanaan layanan Bimbingan dan Konseling tidak berjalan sesuai ketentuan karena peserta didik/konseli menganggap Guru Bimbingan dan Konseling/Konselor adalah polisi sekolah yang akan memberi sanksi atau hukuman kepada mereka yang sedang bermasalah. Padahal tugas dan fungsi pokoknya adalah membantu perkembangan peserta didik seoptimal mungkin.

Kesenjangan kondisi tersebut, tentuharus segera dicarikan solusinya, karena jika dibiarkan, maka peran dan fungsi guru Bimbingan dan Konseling/Konselor tidak bisa optimal.Untuk menyelesaikan kesenjangan antara kondisi yang diharapkan dengan kondisi nyata di lapangan, penulis mengharapkan adanya keterlibatan dari berbagai pihak. Dari permasalahan inilah penulis tertarik untuk membuat artikel Optimalisasi Peran dan Fungsi Guru Bimbingan dan Konseling Dalam Implementasi Kurikulum 13.

\section{KajianPustaka}

PadaPeraturanMenteriPendidikanDanKebudayaa

n RepublikIndonesiaNomor111 Tahun2014 Tentang BimbinganDanKonseling Pada PendidikanDasar DanPendidikanMenengah menyebutkan bahwa;

1. dalam rangka pengembangan kompetensi hidup,konseli memerlukan sistemlayanan pendidikan disatuan pendidikan yang tidak hanya mengandalkan layanan pembelajaran mata pelajaran/bidang studi dan manajemen,tetapijugalayananbantuankhususy anglebihbersifat psiko-edukatif melalui layanan bimbingan dan konseling;

2. setiapkonselisatudenganlainnyaberbeda kecerdasan, bakat, minat,kepribadian,kondisi fisikdan latar belakang keluarga serta pengalaman belajar yang menggambarkanadanyaperbedaanmasalahyan gdihadapikonselisehinggamemerlukanlayana nBimbingandan Konseling;

3. Kurikulum 2013 mengharuskan peserta didikmenentukan peminatan akademik, vokasi, dan pilihanlintas peminatan serta pendalaman peminatan yang memerlukan layananbimbingan dan konseling; 
Menurut ABKIN (2008), ditinjau dari segi fungsinya, layanan bimbingan dan konseling dapat berfungsi sebagai berikut:

a. Fungsi pemahaman, yaitu fungsi bimbingan dan konseling membantu konseli agar memiliki pemahaman terhadap dirinya dengan harapan konseli mampu mengembangkan potensi dirinya secara optimal, dan menyesuaikan dirinya dengan lingkungan secara dinamis dan konstruktif.

b. Fungsi fasilitasi, yaitu memberikan kemudahan kepada konseli dalam mencapai pertumbuhan dan perkembangan yang optimal, serasi, selaras dan seimbang seluruh aspek dalam diri konseli.

c. Fungsi penyesuaian, yaitu fungsi bimbingan dan konseling dalam membantu konseli agar dapat menyesuaikan diri dengan diri dan lingkungannya secara dinamis dan konstruktif.

d. Fungsi penyaluran, konselor perlu bekerjasama dengan pendidik lainnya di dalam maupun di luar lembaga pendidikan.

e. Fungsi adaptasi, yaitu fungsi membantu para pelaksana pendidikan, untuk menyesuaikan program pendidikan terhadap latar belakang pendidikan, minat, kemampuan, dan kebutuhan konseli.

f. Fungsi pencegahan (Preventif), yaitu fungsi yang berkaitan dengan upaya konselor untuk senantiasa mengantisipasi berbagai masalah yang mungkin terjadi dan berupaya untuk mencegahnya, supaya tidak dialami oleh konseli.

g. Fungsi perbaikan, yaitu fungsi bimbingan dan konseling untuk membantu konseli sehingga dapat memperbaiki kekeliruan dalam berfikir, berperasaan dan bertindak (berkehendak).

h. Fungsi penyembuhan, yaitu fungsi bimbingan dan konseling yang bersifat kuratif. Fungsi ini berkaitan erat dengan upaya pemberian bantuan kepada konseli yang telah mengalami masalah, baik menyangkut aspek pribadi, sosial, belajar, maupun karir. Teknik yang dapat digunakan adalah konseling, dan remedial teaching.

i. Fungsi pemeliharaan, yaitu fungsi bimbingan dan konseling untuk membantu konseli supaya dapat menjaga diri dan mempertahankan situasi kondusif yang telah tercipta dalam dirinya. Pelaksanaan fungsi ini diwujudkan melalui program-program yang menarik, reflektif, dan fakultatif (pilihan) sesuai dengan minat konseli.

j. Fungsi pengembangan, yaitu fungsi bimbingan dan konseling yang sifatnya lebih proaktif dari fungsi-fungsi lainnya. Teknik bimbingan yang dapat digunakan di sini adalah pelayanan informasi, tutorial, diskusi kelompok atau curah pendapat (brain stroming), home room, dan karyawisata.

BerdasarkanPermendikbud No. 111 Tahun 2014 tentangBimbingandanKonselingpadaPendidikanD asardanPendidikanMenengahmenjadiacuanpadap enyusunanPanduanOperasionalPenyelenggaraanB imbingandanKonselingSMP (Ditjen GTK Kemdikbud RI, 2016), jugamenyebutkanfungsidariBimbingandanKonsel ingyaitu :

1. Pemahaman diri dan lingkungan;

2. Fasilitasi pertumbuhan dan perkembangan;

3. penyesuaian diri dengan diri sendiri dan lingkungan;

4. penyaluran pilihan pendidikan, pekerjaan, dan karir;

5. pencegahan timbulnya masalah;

6. perbaikan dan penyembuhan;

7. pemeliharaan kondisi pribadi dan situasi yang kondusif untuk perkembangan diri Konseli;

8. pengembangan potensi optimal;

9. advokasi diri terhadap perlakuan diskriminatif;

10.membangun adaptasi pendidik dan tenagakependidikan terhadap program dan aktivitas pendidikan sesuai dengan latarbelakang pendidikan, bakat, minat, kemampuan, kecepatan belajar dan kebutuhan konseli.

DisampingmemberikanlayananBimbingandanKo nselingkepadakonselisecaralangusng , seorang guru

BimbingandanKonselingjugadituntutuntukbisame mberikanlaporansecaratertulispelaksanaanlayanan yang dilakukansesuaidenganPeraturan Menteri Pendidikan Dan Kebudayaan Republik Indonesia Nomor 15 Tahun 2018 Tentang Pemenuhan Beban Kerja Guru, Kepala Sekolah, Dan Pengawas Sekolah disebutkan; Pelaksanaan beban kerja selama 37,5 (tiga puluh tujuh koma lima) jam kerja efektif sebagaimana dimaksud pada Pasal 2 ayat (2) bagi Guru mencakup kegiatan 
a. Merencanakan pembelajaran atau pembimbingan;

b. Melaksanakan pembimbingan;

c. Menilai hasil pembelajaran atau pembimbingan;

d. Membimbing dan melatih konseli; dan

e. Melaksanakan tugas tambahan yang melekat pada pelaksanaan kegiatan pokok sesuai dengan BebanKerja Guru

f. Merencanakan pembelajaran atau pembimbingansebagaimanadimaksudmeliputi

a.Pengkajian kurikulum dan silabus pembelajaran/ pembimbingan/program kebutuhan khusus pada satuan pendidikan;
b. Pengkajian program tahunan dan semester;dan
c.Pembuatan rencana pelaksanaan pembelajaran/pembimbingansesuaistandarpr oses atau rencana pelaksanaan pembimbingan.

Melaksanakan pembelajaran atau pembimbingan sebagaimana dimaksudmerupakan pelaksanaan dariRencana Pelaksanaan Pembelajaran (RPP)/Rencana Pelaksanaan Layanan (RPL)/Rencana Pelaksanaan Bimbingan(RPB).

Pelaksanaanpembelajaransebagaimanadimaksudd ipenuhipalingsedikit 24(duapuluhempat) jamTatapMukaperminggudan

palingbanyak40(empatpuluh) jamTatap Mukaper minggu.

Dari pernyataan di atas sangatjelasbahwa guru BimbingandanKonselingmemilikifungsidanperan yang pentingdalampendidikan, terutama untuk memfasilitasi satuan pendidikan dalam mewujudkan proses pendidikan dengan memperhatikan dan menjawab ragamkemampuan,

kebutuhandanminatsesuaikarakterkonseli.

Keberadaan guru BimbingandanKonselingjuga sangatdibutuhkanolehkonseliuntukbisamembantu mencapaitahapperkembangansesuaiusianya.

\section{Tujuan}

1.1. Mengoptimalkan peran dan fungsi guru Bimbingan dan Konseling/Konselordalam pendidikan di sekolah

1.2. Guru Bimbingan dan Konseling/Konselor memahami peran dan fungsinya

1.3. Guru Bimbingan dan Konseling/Konselor melakukan penguatan dan penegasan peran secara profesional

\section{PEMBAHASAN}

Tujuan pendidikan (Kemdiknas)sebagaimana disebutkan dalam: "Undang-Undang Nomor 20 tahun 2003 tentang Sistem Pendidikan Nasional, Pasal 3, yaitu tujuan mengembangkan potensi peserta didik agar menjadi manusia yang beriman dan bertakwa kepada Tuhan Yang Maha Esa, berakhlak mulia, sehat, berilmu, cakap, kreatif, mandiri, dan menjadi warga negara yang demokratis serta bertanggung jawab."

Dalam Panduan Operasional Penyelenggaraan Bimbingan Dan Konseling Sekolah Menengah Pertamadisebutkan bahwa penyelenggaraan pendidikan yang bermutu dan efektif adalah mengintegrasikan tiga komponen sistem pendidikan yang meliputi komponen manajemen dan kepemimpinan,pembelajaran yang mendidik, serta bimbingan dan konseling yang memandirikan. Ketigakomponen tersebut memiliki wilayah garapan sendiri-sendiri yang saling melengkapi dalamupaya tercapainya tujuan pendidikan nasional. Kejelasan wilayah garapan antara guru matapelajaran dengan guru bimbingan dan konseling atau konselor berdasarkan Disain Induk Penyelenggaraan Bimbingan dan Konseling (2016) dapat dilihat pada tabel berikut : 
Tabel Keunikan dan Keterkaitan Pelayanan Guru Mata Pelajaran dengan Guru Bimbingan dan Konseling atau Konselor

\begin{tabular}{|c|c|c|c|}
\hline Se & Dimaral & Combinta Flagerse & 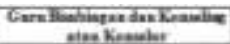 \\
\hline 1. & miend Gene & 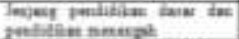 & 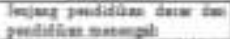 \\
\hline 2 & Tyeus thain & 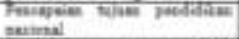 & 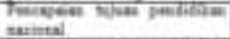 \\
\hline \multirow[t]{2}{*}{1} & 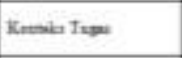 &  & 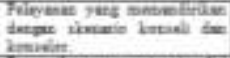 \\
\hline & 11. Fibu Kopient & 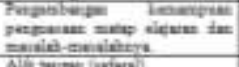 & 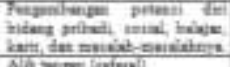 \\
\hline \multirow[t]{3}{*}{2} & 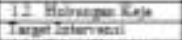 & 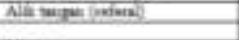 & 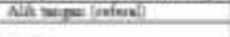 \\
\hline & 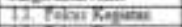 & 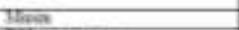 & Thang \\
\hline & 12 Thentapine & Pilanters & Plinatroes \\
\hline \multirow[t]{6}{*}{1} & $\frac{11 \text { sandue }}{12}$ & $t=$ & Hime \\
\hline & 11 tomin & Thentosis & 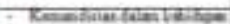 \\
\hline & andertaile &  & 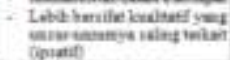 \\
\hline & 12 Terfinatinits & 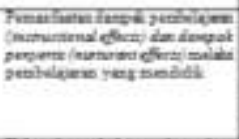 & 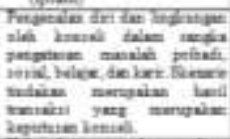 \\
\hline & 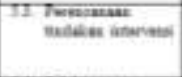 & 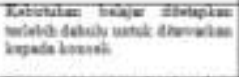 & 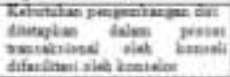 \\
\hline & 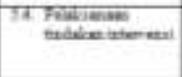 & 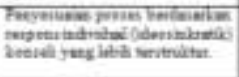 & 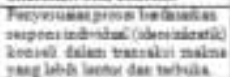 \\
\hline
\end{tabular}

Dari penjelasan tentang tujuan pendidikan serta penyelenggaraan pendidikan yang efektif dan bermutu, bimbingan dan konseling memiliki peran dan fungsi memfasilitasi perkembangan peserta didik/konseli untuk mencapai kemandirian dalam wujud kemampuan memahami diri dan lingkungan, menerima diri, mengarahkan diri, dan mengambil keputusan, serta merealisasikan diri secara bertanggung jawab, sehingga bahagia dan sejahtera dalam kehidupannya

Disamping itu Bimbingan dan konseling pada satuan pendidikan juga diselenggarakan untuk membantupeserta didik/konseli dalam mencapai tugas-tugas perkembangannya. Gurubimbingandankonselingataukonselordisekolah berperanmembantutercapainya perkembangan pribadi, sosial, belajar, dan karir konseli, menjalankansemuafungsibimbingandankonseling yaitufungsipemahaman,fasilitasi,penyesuaian,penya luran,adaptasi,pencegahan,perbaikan,

advokasi,pengembangan,danpemeliharaan.Meskipu ngurubimbingandankonselingatau konselor memegang peranan kunci dalam sistem bimbingan dan konseling di sekolah, dukungandarikepalasekolah dan seluruh komponen sekolahsangatdibutuhkan.

Sebagaipenanggungjawabpendidikandisekolah,kep alasekolahbertanggung

jawabterhadappenyelenggaraanlayananbimbingand ankonseling.Gurubimbingandan

konseling/konselorharusmampu

berkolaborasidenganpemangkukepentinganlainsepe rtiguru

matapelajaran,walikelas,komitesekolah,orang

tuapesertadidik, danpihak-pihaklainyang relevan sesuai wilayah garapan masing-masing sebagaimana bisa dilihat pada Tabel 1 di atas.

Dalam kegiatan proses belajar mengajar di sekolah, setiap peserta didik memiliki kemampuan yang berbeda. Perbedaan ini dapat menimbulkan kesenjangan antara harapan dan kenyataan. Harapannya adalah semua peserta didik mampu mengikuti kegiatan proses belajar mengajar sesuai jadwal yang telah ditentukan dalam pencapaian nilai tertentu/kriteria capaian tertentu.Kenyataan di lapangan kemampuan setiap peserta didik tidak sama. Hal ini sebagaimana yang penulis amati disebabkan oleh berbagai faktor. Disinilah peran dan fungsi guru Bimbingan dan Koseling/ Konselor. Diketahui bahwa pengembangan kompetensi hidup memerlukan sistem layanan pendidikan pada satuan pendidikan yang tidak hanya mengandalkan layanan pembelajaran mata pelajaran/bidang studi dan manajemen saja, tetapi juga layanan khusus yang bersifat psiko-edukatif melalui layanan bimbingan dan konseling, serta memfasilitasi mereka secara sistematik, terprogram, dan kolaboratif agar setiap peserta didik/konseli betul-betul mencapai kompetensi perkembangan atau pola perilaku yang diharapkan.

Menurut Sunaryo Kartadinata Profesor Ilmu Pendidikan bidang Bimbingan dan Konseling Universitas Pendidikan Indonesia, dalam paparannya tentang Kerangka Pikir Pemberdayaan Bimbingan Dan Konseling Dalam Implementasi Kurikulum 2013 menggambarkan posisi dan peran bimbingan dan konseling sebagai berikut ;

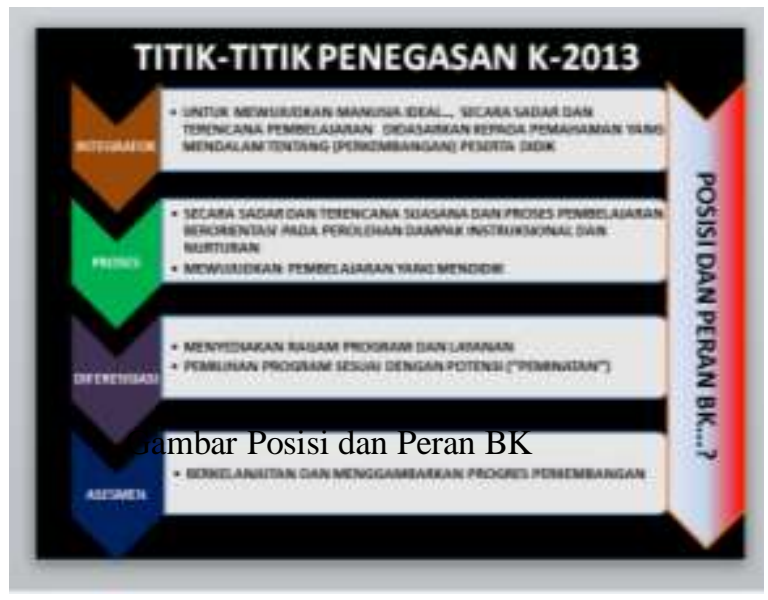


1. INTEGRATOR : Untuk mewujudkan manusia ideal,secara sadar dan terencana pembelajaran didasarkan kepada pemahaman yang mendalam tentang (perkembangan)

konseli.BimbingandanKonselingsebagai bagian integral dari sistem pendidikan di sekolah memiliki peranan penting berkaitan dengan peningkatan mutu pendidikan di sekolah.Denganmemanfaatkan bimbingan dan konseling sebagai mitra kerja dalam melaksanakan tugasnya sebagai rangkaian upaya pemberian bantuankepadakonseli.Guru Bimbingan dan Konseling / Konselor memfasilitasi pengembangan perilaku jangka panjang dalam kerangka pencapaian tujuan utuh pendidikan nasional (TUPN).

\section{PROSES :}

- Secara sadar dan terencana suasana dan proses pembelajaran berorientasi pada perolehan dampak instruksional dan nurturan (nurturan=memberi bantuan, yaitu kebutuhan atau dorongan untuk senang menolong kawan yang kesulitan, membantu yang kurang beruntung, memperlakukan orang lain dengan baik dan simpatik, memaafkan orang lain, menyenangkan orang lain, berbaik hati kepada orang lain, memberikan rasa simpatik kepada yang terluka atau sakit, memperlihatkan kasih sayang kepada orang lain

- Mewujudkan pembelajaran yang mendidik

Pelaksanaanlayananbimbingandankonselingsen antiasamemperhatikanlandasan, pengertian, tujuan, fungsi, azas, prinsip, strategi, langkahlangkahbimbingandankonseling.

Guru Bimbingan dan Konseling /Konselor ; mendukung perwujudan pembelajaran yang mendidik melalui penerapan prinsip bimbingan dan konseling dlm pembelajaran

\section{DEFERENSIASI (PEMINATAN)}

- Menyediakan ragam program dan layanan

- Pemilihan program sesuai dengan potensi ("peminatan")

Program bimbingan dan konseling di Sekolah Menengah Pertama disusun berdasarkan kebutuhan peserta didik/konseli dan kebutuhan sekolah.Guru konselor. Sebutan guru pembimbing sudah harus diganti dengan sebutan konselor (sebagaimana sudah ditegaskan dalam UU No. 20 tahun 2003). Konselor adalah orang yang memliki latar belakang pendidikan bimbingan dan konseling dan memperoleh latihan khusus sebagai konselor, dan memiliki lisensi untuk melaksanakan bimbingan dan konseling.

4. Membangun standar supervisi. Supervisi yang dilakukan oleh orang yang tidak memahami
Bimbingan dan Konseling / Konselor sebagai advokasi aksesibilitas pilihan program dan layanan serta rekayasa lingkungan perkembangan

\section{ASSESMEN}

- Berkelanjutan Dan Menggambarkan Progres Perkembangan

Guru Bimbingan dan Konseling / Konselor melakukan asesmen proses dan hasil, diagnosis masalah perkembangan dan belajar serta bantuan penanganannya

Dari uraian diatas sudah jelas peran dan fungsi Bimbingan dan Koseling. Agar Bimbingan dan Konseling di sekolah berfungsisecaraoptimal selain mengoptimalkan fungsi dan peran sebagai guru Bimbingan dan Konseling/Konselor diperlukan diperlukan juga melakukan penguatan dan penegasan peran dan identitas profesi.

Adapun langkah-langkah penguatan dan penegasan peran dan identitas profesi menurut Sunaryo Kartadinata, Profesor Ilmu Pendidikan bidang Bimbingan dan Konseling)yang biasa kita lakukan antara lain

1. Memahamkan Para Kepala Sekolah

Dukungan kepala sekolah dalam implementasi dan penanganan program Bimbingan dan Konseling di sekolah, sangat esensial. Hubungan antara kepala sekolah dengan konselor sangat penting di dalam menentukan keefektifan program.

2. Membebaskan konselor dari tugas yang tidak relevan

Masih ada konselor sekolah yang diberi tugas mengajar bidang studi, bahkan mengurus halhal yang tidak relevan dengan Bimbingan dan Konseling, seperti menjadi petugas iket, perpustakaan, koperasi, dsb. Tugas-tugas yang tidak relevan dengan latar belakang pendidikan tidak akan menjadikan bimbingan dan konseling dilaksanakan secara profesional.

3. Mempertegas tanggung jawab konselor

Sudah saatnya menegaskan bahwa bimbingan dan konseling menjadi tanggung jawab dan kewenngan

atau tidak berlatar belakang bimbingan dan konseling bisa membuat perlakuan supervisi bimbingan dan konseling disamakan dengan perlakuan terhadap guru mata pelajaran. Akibatnya balikan yang diperoleh konselor dari pengawas bukanlah hal-hal yang substantif tentang kemampuan bimbingan dan konseling melainkan hal-hal teknis administratif. 
Seorang Guru Bimbingan dan Konseling/konselor harus menunjukkan kinerjanya secara profesional dengan;

- Menjalankan peran dan fungsi secara optimal dalam membantu siswa keluar dari kesulitannya seperti; mengatasi kesulitan belajar dengan mengetahui penyebabnya, memilih dan menentukan arah peminatan sesuai dengan potensi dirinya, serta bersikap tegar dalam menghadapi kesulitan hidup yang dihadapi dan yang akan dihadapi.

- Harus bekerja secara profesional sesuai dengan tugas pokok dan fungsinya.

- Selalu meningkatkan kompetensinya dengan mengikuti berbagai kegiatan yang relevan.

- Menampilkandiri sebagai konselor dengan program kerja yang jelas dan siap untuk melaksanakan.

- Bertanggung jawab dalam memahami peranannya sebagai konselor profesional dan menterjemahkan peranannya ke dalam kegiatan nyata.

Konselor juga harus menunjukkan kemartabatan profesi dalam kinerjanya dengan ;

- Keinginan menampilkan perilaku yang mendekati standar ideal;

- Meningkatkan dan memelihara citra profesi;

- Keinginan mengejar kesempatan pengembangan profesional;

- Mengejar kualitas dan cita-cita dalam profesi; dan

- Memiliki kebanggaan terhadap profesi.

Optimalisasi peran guru bimbingan dan konseling/konselor harus ditunjukan dengan adanya kemampuan, kemauan, dankesiapan belajar yang dilandasi oleh sikap, nilai, etika dan moralselain untuk membantu peserta didik dalam arah peminatan yang diamanatkan dalam kurikulum 2013 juga membantu peserta didik dalam mengembangkan potensinya seoptimal mungkin.

Seorang guru bimbingan dan konseling/konselor harusmemiliki kompetensi dalam hal ;

- memahami secara mendalam peserta didik yang hendak dilayani;

- menguasai landasan teoretik keilmuan pendidikan dan Bimbingan dan Konseling;

- menyelenggarakan pelayanan Bimbingan dan Konseling secara profesional;

- mengembangkan pribadi dan profesionalitas diri secara berkelanjutan dengan mengikuti berbagai kegiatan pengembangan diri berkelanjutan.

Profesionalisasimenunjukkepada proses peningkatankualifikasidankompetensiguru BKsebagaianggotaprofesidalammencapaikriteriasta ndardalamkinerjanyamenjalankantugasutamaprofes i.Profesionalisasimerupakankeharusanbagisetiap orang yang menjalankanprofesi, agar dapatmemenuhituntutanstandar profesi.

Oleh karena itu Guru BK harus mempunyai komitmen yang tinggi dalam upaya untuk meningkatkan kualifikasi dan kemampuan profesionalnya untuk mencapai standar profesi yang ditetapkan. Profesionalisasi akan membentuk guru BK Profesional dan Bermartabat.

Profesi Bimbingan dan Konseling dibutuhkan dalam Implementasi kurikulum 2013 terkait dengan tujuan pendidikan nasional yaitu mengembangkan potensi peserta didik agar menjadi manusia yang beriman dan bertakwa kepada Tuhan Yang Maha Esa, berakhlak mulia, sehat, berilmu, cakap, kreatif, mandiri, dan menjadi warga negara yang demokratis serta bertanggung jawab serta menentukan arah peminatan sesuai dengan potensi dirinya, diperlukan Guru Bimbingan dan Konseling atau Konselor yang kompeten, profesional, bermartabat sehingga mampu menjalankan peran dan fungsi profesi BK secara optimal

\section{PENUTUP}

\section{Kesimpulan}

Ada beberapa hal yang harus dilakukan dalam mewujudkan Implementasi kurikulum 2013 terkait dengan arah peminatan siswa, Guru Bimbingan dan Konseling atau Konselor yang kompeten, profesional, bermartabat sehingga peran dan fungsi profesi BK dapatdilaksanakansecara optimal, yaitu ;

1. Optimalisasi peran guru bimbingan dan konseling/konselor harus ditunjukan dengan adanya kemampuan, kemauan, dankesiapan belajar yang dilandasi oleh sikap, nilai, etik dan moraluntuk membantu peserta didik

2. Dengan menjalankan peran dan fungsi secara optimal dalam membantu peserta didik sesuai dengan potensi dirinya, makarangkaianlayanan yang diberikan guru BimbingandanKoselingberjalansesuai yang diprogramkan

3. Denganmemberikanpenguatandanpenegas anidentitas guru BimbingandanKonselingkepadaseluruhko mponen yang ada di sekolah, makakualifikasidankemampuannyasesuaiS tandar Kualifikasi Akademik dan Kompetensi Konselor (SKAKK)

Saran :

Berikut ini dikemukakan saran-saran yang dapat dijadikan sebagai bahan pertimbangan, kepada : 
1. Dengan adanya penulisan artikel ini diharapkan guru Bimbingan dan Konseling, bisa melaksanakan tugassesuaifungsinyadengan

selalubekerjasamadanberkolaborasidengansemuapi hakdisekolahdalampembuatan program BimbingandanKonseling

2. Guru

BimbingandanKonselingselalumengupdatedanmen gupgradekeilmuannyadenganmengikutipelatihan, workshop,

seminar, literasidanmelanjutkanjenjangpendidikan yang lebihtinggilagi

3. Penelitianinibersifat internal, bagipeneliti lain bisamengembangkanpenelitianinidenganmetodepen elitian yang lain

\section{DAFTAR PUSTAKA}

Asosiasi Bimbingan Konseling Indonesia ( ABKIN). Panduan Khusus Bimbingan dan Konseling. Pelayanan Arah Peminatan Peserta Didik, 2013.Jakarta.

Daryanto \& Mohammad Farid.2015. Bimbingan Konseling Panduan Guru BK dan Guru Umum. Malang : Gava Media.

Kartadinata, Sunaryo. , Profesor Ilmu Pendidikan bidang Bimbingan dan Konseling) 2018. Kerangka Pikir Pemberdayaan Bimbingan Dan Konseling Dalam Implementasi Kurikulum $2013 \quad$ (on line) (https://akhmadsudrajat.files.wordpress.com/2 013/.../kerangka-pikir-pemberdayaanbimbingan-dan-konseling.diunduh September 2018

Kementerian Pendidikan Dan Kebudayaan. Dirjen Pendidikan

Dasar.PanduanOperasionalPenyelenggaraan BimbingandanKonselingSekolahMenengah Pertama (SMP), 2016. Jakarta

Kementrian Pendidikan Dan Kebudayaan, Dirjen Pendidikan Dasar.BukuPanduanBimbingandanKonselin g danPedomanPenelusuranMinatPesertaDidik, 2013. Jakarta

Kementrian Pendidikan Dan Kebudayaan. Dirjen Pendidikan Dasar.Pedoman Penelusuran Minat Peserta Didik Sekolah Menengah Pertama, 2013. Jakarta

Prayitno, 2012. Jenis Layanan dan Kegiatan Pendukung Konseling.Program Pendidikan Profesi Konselor. Jurusan Bimbingan dan Konseling .FKIP Universitas Padang . Padang

Sugiyono .2011. Metode Penelitian Pendidikan Pendekatan Kuantitatif,Kualitatif, dan $R \&$ $D$. Bandung :Alfabeta 